\title{
Impact of Single or Fractionated Radiation and Selenium Nano-particles on Acid Lime (Citrus aurantifolia L.) Seed Germination Ability and Seedlings Growth.
}

\author{
Hussein S.Ahmed,' Mohamed F.Ahmed, ${ }^{2}$ Tahsin Shoala, ${ }^{3}$ M. Salah ${ }^{4}$ \\ 'Horticulture Research Institute, Agricultural Research Center, Giza, Egypt \\ ${ }^{2}$ Natural Products Dept., National Centre for Radiation Research and Technology, Atomic Energy Authority, Cairo, Egypt. \\ ${ }^{3}$ College of Biotechnology, Misr University for Science and Technology, 6th of October city, Egypt. \\ ${ }^{4}$ Polymer Chemistry Dept., National Centre for Radiation Research and Technology,Atomic Energy Authority, Cairo, Egypt.
}

Correspondence: Hussein S. Ahmed, Horticulture Research Institute, Agricultural Research Center, Egypt,

Email: Husseinsayed72@yahoo.com

Received: July 13,2018 | Published: September 25, 2018

Copyright@ 2018 Ahmed et al. This is an open access article distributed under the terms of the Creative Commons Attribution License, which permits unrestricted use, distribution, and reproduction in any medium, provided the original author and source are credited.

\begin{abstract}
In the present study, seeds of acid lime (Citrus aurantifolia L.) were radiated with gamma radiation at low dose of 20 Gy as single dose or fractionated doses, part of radiated seeds were soaked in solutions of Nano-selenium at $50 \mathrm{ppm}$, to investigate the effect of treatments on seeds germination ability, seedlings vegetative growth parameters, leaf bio- chemical contents and leaf (macro \& micro) elements, moreover, separation of HMW and LMW protein subunits extracted from all consequent seedling was performed using electrophoresis technique. Obtained results revealed generally that pre-sowing radiation of acid lime seeds with $\gamma$ radiation at $20 \mathrm{~Gy}$, fractionated as 4 doses or as 2 doses and then, soaking irradiated seeds in Nano-selenium solution at (50 ppm) treatment, increase germination percentage by $30 \%$ and $36 \%$ compared with untreated seeds (control) for both seasons, as well as reduced seedlings damping off and albino percentage, and increased seedlings stem length by $52.5 \%$ \& $46.5 \%$, and stem diameter by about $37 \%$ and $36 \%$, also number of leaves/ seedling and leaf area was significantly increased, also cause significant increase in total indoles and reduced total phenols content in acid lime seedling leaves. In addition, both $\gamma$ ray and Nano-(Se) treatment significantly increase accumulation of macro and micro-elements which positively reflected on seedlings vegetative growth. Protein analysis using electrophoresis technique for acid lime seedlings leaves illustrated that, exposure of acid lime seeds to different doses of $\gamma$ ray showed clear separation of protein pattern with no differences with untreated samples (control), which means that acid lime seeds, could be treated with particular low doses gamma radiation without affecting the genotype. Briefly, pre-sowing combination treatments of both $\gamma$ radiation treatment and soaking in Nano-selenium solution at $50 \mathrm{ppm}$, could be helpful in, reducing nursery period and producing vigorous and healthy (acid lime seedlings) with improved quality.
\end{abstract}

Keywords: Citrus, $\gamma$ ray, (Se), nano-particles, acid lime, seedlings, germination ability and nursery.

\section{Introduction}

Citrus industry is the most important fruits types in the world. Acid lime (Citrus aurantifolia L.) is one of the important commercial fruits; fruitful orchards reached approximately 35515 Fed., producing about 350597 tons / year (according to Ministry of Agric. And Land Reclamation / Annual Report 2015). Low productivity may be due to genotypes multiplications. Moreover, acid lime seedlings are largely true to type because of poly-embryony and the juvenile phase lasts about five years. ${ }^{1}$ Propagation of acid lime is generally done by grafting and by seed. The commercial practice of propagation is by seed. The seed of acid lime have polyembryonic nature. The polyembryonic seed emerge in more than two seedlings from one seed. Out of them, one seedling is vigorous which is produced from the somatic cells of the nucleus. Sexually raised plants have extensive root system and bear intense crop. Nurserymen and growers faced the problems of seeds low storage ability poor seed germination and less vigorous seedlings. ${ }^{2}$
The emergence and establishment of uniform and hearty seedlings could be achieved in many crops by radiating seeds, recently, seed radiation have been used on a large scale to increase rate and percentage of seed germination, improving rate of elongation in young seedlings and stimulate the growth of various parts of plants. ${ }^{3,4}$

Radiation dose had significant effect on growth parameters and germination, in this concern ${ }^{5}$ radiating seeds of rough lemon (Citrus jambhiri Lush.) with relatively low-doses of ionizing irradiation ,accelerated cell proliferation, cell growth and germination rate , moreover, Maity et al. ${ }^{6}$ mention that, increasing radiation dose may cause adverse effect. Which may be explain as that, low dose of gamma radiation stimulates cell division and high-dose inhibits cell division due to free radicals, DNA system damage and expression of genes related to callus. ${ }^{7,8}$

Selenium (Se) is a naturally occurring metalloid element which occurs nearly in all environments. When Se added at low concentrations, exert beneficial effects on plant growth and it as quasi-essential micronutrient
Submit your Article | www.ologyjournals.com/submit-article 
through changing different biochemical and physiological characters. Several reports show that, selenium applications show positive effect on seed germination and seedlings growth. ${ }^{9-11}$

Nanotechnology is a new approach that refers to understand the properties of matter at the Nano-scale (one Nano-meter $=$ one billion of meter) which is the length of a small molecule. At this level, matter exhibits different physical, chemical, and biological properties that provide new applications for existing materials. ${ }^{12-14}$

The current study was undertaken to assess the effect of low $\gamma$ radiation as single or fractionated doses and soaking in selenium Nano-particles on acid lime (Citrus aurantifolia L.) seed germination ability and consequently the growth of their seedlings in order to reduce nursery period and produce vigorous and healthy seedlings.

\section{Materials and Methods}

This investigation was carried out during two successive seasons (2015/2016 and 2016/2017) aiming at investigating the physiological effect of low gamma as single or fractionated doses and Nano-(Se) application on seeds germination ability and physiological status of acid lime (Citrus aurantifolia L.) seedlings. The present study was performed in a saran house at Horticultural Research Institute, Agricultural Research Center, MOA, Giza, Egypt.

\section{Plant material}

In mid-February, for each season of study, seeds of acid lime were obtained from mature homogenate fruits of adult trees. Seeds were extracted, washed and air dried, preserved at $3^{\circ} \mathrm{C}$.

\section{Gamma irradiation}

At the end of March, for both seasons, the dry acid lime seeds were irradiated with Gamma $(\gamma)$ radiation using Gamma-Cell Co60, Atomic Energy Authority. Doses of $\gamma$ radiation were (20 Gray (Gy) as a single dose) or fractionated as (2 doses of 10 Gy each at 2 days) or ( 4 doses of 5 Gy each at 4 days). Part of acid lime seeds were not irradiated representing control for radiation treatment $(0.0$ Gy). Dose rate were 2.028 and $1.776 \gamma$ radiation $/ \mathrm{min}$, respectively. Irradiated seeds as well as the control seeds $0.0 \gamma$ radiations were, soaked immediately in Nano-selenium solutions at (50 ppm Nano$\mathrm{Se})$, part of irradiated seeds were soaked in water representing control for soaking treatment $(0 \mathrm{ppm}$ Nano-Se). All seeds were planted at the beginning of April, for both seasons of study, in $4 \mathrm{~kg}$ plastic bags , planting medium was mixture of peat moss and washed sand in ratio 1:3. All bags were irrigated immediately after sowing, and then the irrigation was carried out one time every two days with tap water. Each bag contains 5 seeds to represent one replicate, and each of the 8 treatments was represented by ten replicates. The planted bags were arranged in the nursery in factorial randomization completely block design with 8 treatments each have 10 replicates.

\section{Applied treatments were as follow:}

1. Control not irradiated (soaking in tap water) (Nano-Se at $0 \mathrm{ppm}$ +0 Gy $\gamma$ ray).

2. Gamma radiation at $20 \mathrm{~Gy}$ fractionated as 4 doses, each of $5 \mathrm{~Gy}$ (Nano-Se at $0 \mathrm{ppm}+20 \mathrm{~Gy} \gamma \mathrm{ray} / 4 \mathrm{D})$.

3. Gamma radiation at $20 \mathrm{~Gy}$ fractionated as 2 doses, each of $10 \mathrm{~Gy}$ (Nano-Se at $0 \mathrm{ppm}+20 \mathrm{~Gy} \gamma \mathrm{ray} / 2 \mathrm{D})$.

4. Gamma radiation at $20 \mathrm{~Gy}$ as single dose (Nano-Se at $0 \mathrm{ppm}+20$ Gy $\gamma$ ray/1D).
5. Soaking in Nano-selenium at $50 \mathrm{ppm}$, not irradiated (Nano-Se at $50 \mathrm{ppm}+0$ Gy $\gamma$ ray).

6. Soaking in Nano-selenium at $50 \mathrm{ppm}+\gamma$ radiation at $20 \mathrm{~Gy}$ fractionated as 4 doses, each of 5 Gy (Se at $50 \mathrm{ppm}+20$ Gy $\gamma$ ray/4D).

7. Soaking in Nano-selenium at $50 \mathrm{ppm}+\gamma$ radiation at $20 \mathrm{~Gy}$ fractionated as 2 doses, each of $10 \mathrm{~Gy}$ (Se at $50 \mathrm{ppm}+20 \mathrm{~Gy} \gamma$ ray/2D).

8. Soaking in Nano-selenium at $50 \mathrm{ppm}+\gamma$ radiation at 20 Gy as single dose (Se at $50 \mathrm{ppm}+20 \mathrm{~Gy} \gamma$ ray/1D).

Agricultural practices were applied as the Citrus Res. Dept. recommendation for citrus nurseries during the two successive seasons $(2015 \& 2016)$ respectively. Germination process data were weekly recorded until became constant. At September, ten plants for each treatment were taken.

\section{Measurements and Analysis:}

Effects of investigated treatments were evaluated through the following measurements:

\section{Seeds germination stage:}

The following parameters of seed germination were determined according to Hartmann and Kaster (1983) ${ }^{15}$ as follows:

Germination percentage $=($ Number of germination seeds / Initial number of seeds) X 100 .

Damping off percentage $=($ Number of damped off seedlings $/$ Initial number of seeds) X 100 .

$\begin{array}{lllll}\text { Albino } & \text { percentage } & \text { (Number of } & & \text { albino } \\ \text { seedlings } & \text { / Initial number } & \text { of seeds) } & \text { X } & 100 .\end{array}$

\section{Seedlings Vegetative growth parameters:}

1. Stem length (cm.);

2. Stem diameter $(\mathrm{cm}$.);

3. Number of leaves / seedling and

4. leaf area $\left(\mathrm{cm}^{2}\right)^{2}$ :

Five expanded leaves (about 6 month's age) of spring cycle from each replicate were picked from the middle part of seedling. Leaf area in $\mathrm{cm}^{2}$ was determined by using Planimeter.

\section{3) Bio-chemical contents:}

\section{1) Leaf pigments contents:}

Disks of $2.5 \mathrm{~cm}^{2}$ from the leaves were extracted with dimethyl Formide (D.M.F.) solution [HCON (CH3)2] and kept for $48 \mathrm{~h}$ at temperature $5^{\circ} \mathrm{C}$ in dark conditions. Chlorophyll (a) and (b) as well as carotenoids were measured by Spectrophotometer Beckman Du 7400 at wavelengths 663,647 and $470 \mathrm{MU}$, according to the equation described by Moran ${ }^{16}$ and calculated as (mg/100g FW).

$$
\begin{aligned}
& \text { Chl. } \mathrm{a}=12.70 \mathrm{~A}_{663}-2.79 \mathrm{~A}_{647}{ }^{\circ} \\
& \text { Chl. } \mathrm{b}=20.76 \mathrm{~A}_{647}-4.62 \mathrm{~A}_{663} . \\
& \text { Total Chls }=17.90 \mathrm{~A}_{647}-8.08 \mathrm{~A}_{663} . \\
& \text { Total carotenoids }=1000 \mathrm{XA}_{470}-3.72 \text { chl.a-04chl.b/229. }
\end{aligned}
$$

\section{2) Total Indoles and Phenols:}

Total Indoles was determined as $\mathrm{mg} / \mathrm{g}$ dry weight according to Larsen, ${ }^{17}$ and as modified by Selim et al. ${ }^{18}$ and total Phenols was 
determined as mg. /g. dry weight by using the Folin calorimetric method. ${ }^{19}$

\section{3) Leaf elements content:}

Leaf samples were dried in an oven at $70^{\circ} \mathrm{C}$ for constant weight dried samples was digested as described by Cottenie ${ }^{20}$ digested samples were used to determine content of the following minerals in leaves as follow:

N\% was determined with the modified micro-kjeldahl method as described by Plummer, ${ }^{21} \mathrm{P} \%$ was measured calorimetrically, using the molybdenum blue method and by using Spectrophotometer (Model- Beckman Du 7400) according to Murphy and Riley, ${ }^{22} \mathrm{~K} \%$ was determined against a standard using flame-photometer (ModelJENWAY - pfp7 Flame Photometer) according to $\operatorname{Piper}^{23} \mathrm{Fe}, \mathrm{Zn}$ and $\mathrm{Mn}$ were determined as ppm by using Atomic Absorption Spectrophotometer according to Brandifeld and Spincer. ${ }^{24}$

\section{Protein extraction method and analysis:}

Different plant samples were collected, labelled and grounded by using liquid nitrogen in the mortar and pestle, and then $1 \mathrm{ml}$ of cold QB buffer was added to $1 \mathrm{~g}$ plant powder and mixed vigorously under cooling system. The mix was transferred to $1.5 \mathrm{ml}$ microfuge tube and placed on ice. Samples Span at the highest speed in a microfuge at 4 degrees $C$ for 15 minutes. Supernatant was transferred into new microfuge tube and centrifuged at the highest speed for 10 minutes under cooling system and resulted supernatant was transferred to new microfuge. Samples stored in in -80 degree freezer. SDS-PAGE was performed by the method described by Laemmli. ${ }^{25}$ Proteins were analyzed on $1.5-\mathrm{mm}$ thick and $15-\mathrm{cm}$ long gels run in a dual vertical slab unit (Hoefer Scientific Instruments, San Francisco, CA, USA). From each sample, 25 ul of protein extract was loaded on a polyacrylamide gel. The separation gel $(10 \%)$ and staking gel (3.5\%) were prepared from an acrylamide monomer solution (Roth, Karlsruhe, Germany). Protein was electrophoresed at a constant current of $30 \mathrm{~mA}$ through the stacking gel, and at $90 \mathrm{~mA}$ through the separation gel at room temperature, the gels were stained by silver nitrate. ${ }^{26}$

\section{Preparation of Nano (Se) solutions:}

For Preparing polyvinyl-pyrrolidone (PVP) sodium selenite Nano-gel, $25 \mathrm{~g}$ of polyvinyl-pyrrolidone (PVP) was dissolved in $635 \mathrm{ml}$ distilled water via magnetic stirring then adding $100 \mathrm{~g}$ of sodium selenite at $70^{\circ} \mathrm{C}$. After dissolving, $14 \%$ of acetic acid was added and followed by the addition of $10 \%$ glycerol. The solution was left under stirring until the appearance of pale yellow color. Finally, the solution was irradiated via ${ }^{60} \mathrm{Co}$ gamma irradiator at the irradiation dose $30 \mathrm{k}$ Gy (Allam et al., 2012) ${ }^{27}$.

\section{Statistical analysis:}

The obtained data was subjected to analysis of variances (ANOVA) according to Snedecor and Cochran, ${ }^{28}$ using M-STAT program. Differences between means were compared using Duncan's multiple range tests at 0.05 level. ${ }^{29}$

\section{Results and Discussion}

\section{Seeds germination stage:}

\section{Germination percentage:}

Data in Table (1) indicated that, radiating acid lime seeds with $\gamma$ radiation at $20 \mathrm{~Gy}$, fractionated as 4 doses, increased seed germination percentage significantly to ( $93 \% \& 101 \%$ ) respectively, for both seasons. This increment of germination percentage above $100 \%$ due to the polyembryonic phenomenon in acid lime seeds..$^{30,31}$ Our data are in harmony with those obtained by Sharma et al. ${ }^{5}$ since the doses used in is below mutagenic doses they reported that , 60 Gray were observed to be the optimum mutagenic dose of gamma rays for 40 day old seeds of rough lemon (Citrus jambhiri Lush); Ling et al. ${ }^{32}$ on (Citrus sinensis) and Kumar and Mishra ${ }^{33}$ on Okra.

Table I Effect of pre-sowing $\gamma$ radiation and Nano-Se application on acid lime seeds germination stage.

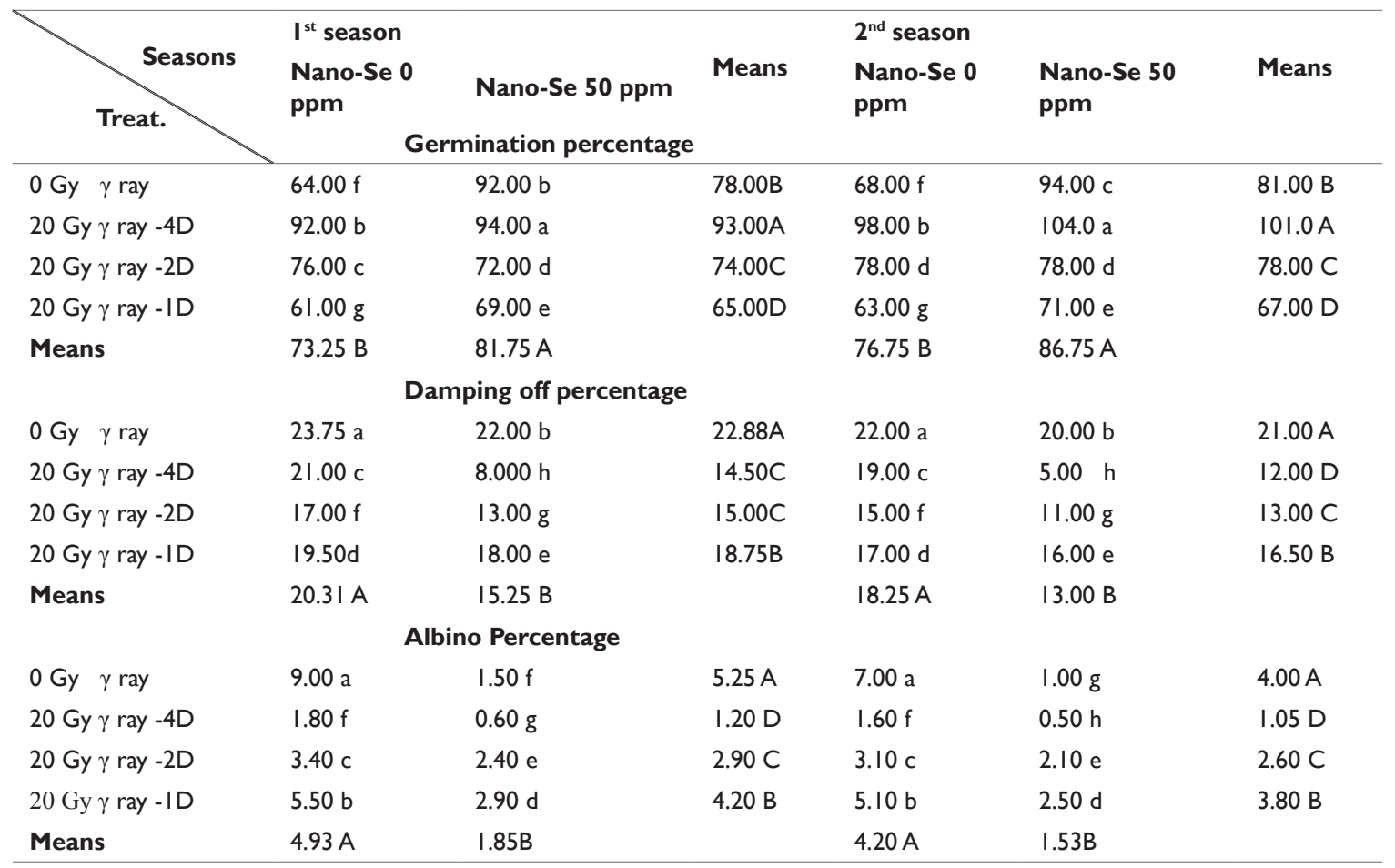

* Mean followed by the same letter are not significantly different at $5 \%$ level.

Citation: Ahmed HS, Ahmed MF, Shoala T, et al. Impact of Single or Fractionated Radiation and Selenium Nano-particles on Acid Lime (Citrus aurantifolia L.) Seed Germination Ability and Seedlings Growth. Adv Agr Environ Sci. (20I8); I(2): 91-I00. DOI: 10.3088I/aaeoa.00016 
With regard to soaking in Nano-selenium solution, presented data showed that, soaking seeds in Nano-selenium solution at 50ppm presowing improved seeds germination percentage significantly to $(81.75$ $\%$ \& $86.75 \%$ ) respectively, during the two experimental seasons. These results are in agreement with those obtained by Shahverdi ${ }^{34}$ on stevia (Stevia rebuadiana Bertoni), Luís et al. ${ }^{35}$ on Triticum aestivum, Aggarwal et al. ${ }^{36}$ on seedlings of Bean (Phaseolus vulgaris L.) and Carlson et al..$^{37}$ on Certified seeds of cabbage, sorgrass and wheat, the germination percentage reached about $100 \%$ with all applied Selenium levels.

As for the interaction effect, results in Table (1) revealed that, radiating acid lime seeds at $20 \mathrm{~Gy}$, fractionated as 4 doses, followed by soaking in Nano-selenium solution at 50ppm resulted in increasing seeds germination percentage to ( $94 \%$ \& $104 \%$ ) respectively for both seasons.

\section{Percentage of Damping off and Albino seedlings:}

Obtained Results in Table (1) declared that, $\gamma$ ray at 20 Gy divided into four doses significantly reduced both seedling damping off Percentage and albino seedlings percentage during the studied seasons.

Concerning seed soaking treatments, presented data indicated that, soaking acid lime seeds in Nano-selenium solution at $50 \mathrm{ppm}$ reduced significantly seedling damping off and albino percentage for both seasons, respectively.

As for the interaction between $\gamma$ radiation and soaking in Nanoselenium solution pre-sowing treatments. It is apparent that, combination treatment of $\gamma$ radiation at $20 \mathrm{~Gy}$, fractionated as 4 doses, followed by soaking in Nano-selenium solution at $50 \mathrm{ppm}$ significantly reduced seedling damping off percentage to $(8 \% \& 5 \%)$ and albino seedling percentage to $(0.6 \% \& 0.5 \%)$ for both seasons, respectively.

It can be concluded that pre-sowing radiation of acid lime seeds by $\gamma$ ray then soaked in Nano-selenium solution at $(50 \mathrm{ppm})$ greatly promoted germination percentage as well as reduced seedlings damping off \& albino percentage , the effect of gamma radiation in encourage seed germination may be attributed to the activation of protein or RNA synthesis, or may perhaps to an increase in rate of respiration or auxin metabolism during the early stage of germination after exposing to low doses of gamma radiation Abdel-Hady et al. ${ }^{38}$ and Jan et al. ${ }^{39}$ From other point of view, El-Ramady et al. ${ }^{11}$, reported that, exposing rough lemon seeds (Citrus jambhiri L.ush) to lowdoses of ionizing radiation accelerated cell proliferation, cell growth, and enzyme activity.

This effect depending on several factors: i" Moisture content and cell chemical constituent. ii" ionization the production of hydrogen peroxide and activate the free radicals.iii) Help to produce the genetic mutations. These results are in line with those obtained by: SpiegelRoy and Kochba ${ }^{40}$, Spiegel-Roy et al., ${ }^{41}$ Lange and Toit, ${ }^{42}$ Vose $^{43}$ and Jawaharlal et al. ${ }^{44}$

\section{Seedlings Vegetative growth parameters:}

As regard to the effect of $\gamma$ ray on acid lime seedlings vegetative growth parameters, data in Table (2) indicated that seedling stem length significantly increased by about $28 \%$ and $30 \%$ for both seasons by exposing to $\gamma$ radiation at $20 \mathrm{~Gy}$, fractionated as 4 doses, moreover that treatment significantly increased other vegetative growth parameters as, stem diameter, number of leaves/ seedling and leaf area, by the same that was conferment. Whereas, the control had the lowest values in both seasons, respectively.

As for, Nano-selenium treatments results in Table (2) disclosed that, soaking acid lime seeds in Nano-selenium solution at $50 \mathrm{ppm}$ presowing significantly increase seedlings stem length, stem diameter, number of leaves/ seedling and leaf area for both seasons. Whereas, soaked seeds in tap water pre-sowing showed the lowest significant values for all studied vegetative growth parameters.

concerning, combination treatment of both $\gamma$ radiation and soaking in Nano- selenium solution pre-sowing, it is obvious from obtained results in Table (2) that, $\gamma$ radiation at $20 \mathrm{~Gy}$, fractionated as 4 doses, followed by soaking in Nano-selenium solution at $50 \mathrm{ppm}$ presowing increased seedling stem length by $52.5 \%$ \& $46.5 \%$ and stem diameter by about $37 \%$ and $36 \%$ for both seasons respectively and significantly increased number of leaves / seedling compared with control treatment. Moreover, $\gamma$ radiation at $20 \mathrm{~Gy}$, fractionated as 2 doses, followed by soaking in Nano-selenium solution at $50 \mathrm{ppm}$ presowing attained the highest leaf area $(23.7 \& 24.6) \mathrm{cm}^{2}$ respectively for both seasons.

Table 2 Effect of pre-sowing $\gamma$ radiation and Nano-Se application on vegetative growth parameters of acid lime seedlings.

\begin{tabular}{|c|c|c|c|c|c|c|}
\hline & $\left.\right|^{\text {st }}$ season & & & $2^{\text {nd }}$ season & & \\
\hline & $\begin{array}{l}\text { Nano-Se } 0 \\
\text { ppm }\end{array}$ & $\begin{array}{l}\text { Nano-Se } 50 \\
\text { ppm }\end{array}$ & Means & $\begin{array}{l}\text { Nano-Se } 0 \\
\text { ppm }\end{array}$ & $\begin{array}{l}\text { Nano-Se } 50 \\
\text { ppm }\end{array}$ & Means \\
\hline \multicolumn{7}{|c|}{ Stem length (cm.) } \\
\hline 0 Gy $\gamma$ ray & $34.67 d$ & $48.33 c$ & $41.50 \mathrm{C}$ & 39.00 e & $58.00 \mathrm{c}$ & $48.50 \mathrm{C}$ \\
\hline 20 Gy $\gamma$ ray $-4 D$ & $66.67 b$ & $73.00 \mathrm{a}$ & $69.83 \mathrm{~A}$ & $68.00 \mathrm{~b}$ & $72.00 \mathrm{a}$ & $70.00 \mathrm{~A}$ \\
\hline 20 Gy $\gamma$ ray $-2 D$ & $51.33 \mathrm{c}$ & $51.00 \mathrm{c}$ & $51.17 \mathrm{~B}$ & $53.00 \mathrm{~d}$ & $52.00 \mathrm{~d}$ & $52.50 \mathrm{~B}$ \\
\hline 20 Gy $\gamma$ ray -ID & $50.00 \mathrm{c}$ & $50.33 c$ & 50.17 B & $53.00 \mathrm{~d}$ & $52.67 d$ & $52.83 \mathrm{~B}$ \\
\hline Means & $50.67 \mathrm{~B}$ & $55.6 \mathrm{~A}$ & & $53.25 \mathrm{~B}$ & $58.6 \mathrm{~A}$ & \\
\hline \multicolumn{7}{|c|}{ Stem diameter $(\mathrm{cm})}$. \\
\hline 0 Gy $\gamma$ ray & $0.26 \mathrm{~d}$ & $0.28 \mathrm{~d}$ & $0.27 \mathrm{C}$ & $0.29 \mathrm{bc}$ & $0.27 c$ & $0.28 \mathrm{BC}$ \\
\hline 20 Gy $\gamma$ ray $-4 D$ & $0.34 \mathrm{bc}$ & $0.4 \mathrm{I}$ a & $0.38 \mathrm{~A}$ & $0.34 \mathrm{~b}$ & $0.45 \mathrm{a}$ & $0.40 \mathrm{~A}$ \\
\hline 20 Gy $\gamma$ ray $-2 D$ & $0.28 \mathrm{~d}$ & $0.35 \mathrm{abc}$ & $0.32 \mathrm{BC}$ & $0.26 \mathrm{c}$ & $0.35 \mathrm{~b}$ & $0.3 \mathrm{IB}$ \\
\hline 20 Gy $\gamma$ ray -ID & $0.31 \mathrm{~cd}$ & $0.39 \mathrm{ab}$ & $0.35 \mathrm{AB}$ & $0.32 \mathrm{bc}$ & $0.32 b c$ & $0.32 \mathrm{~B}$ \\
\hline
\end{tabular}

Citation: Ahmed HS,Ahmed MF, Shoala T, et al. Impact of Single or Fractionated Radiation and Selenium Nano-particles on Acid Lime (Citrus aurantifolia L.) Seed Germination Ability and Seedlings Growth. Adv Agr Environ Sci. (20l8); (2): 9I-I00. DOI: 10.3088 I/aaeoa.00016 


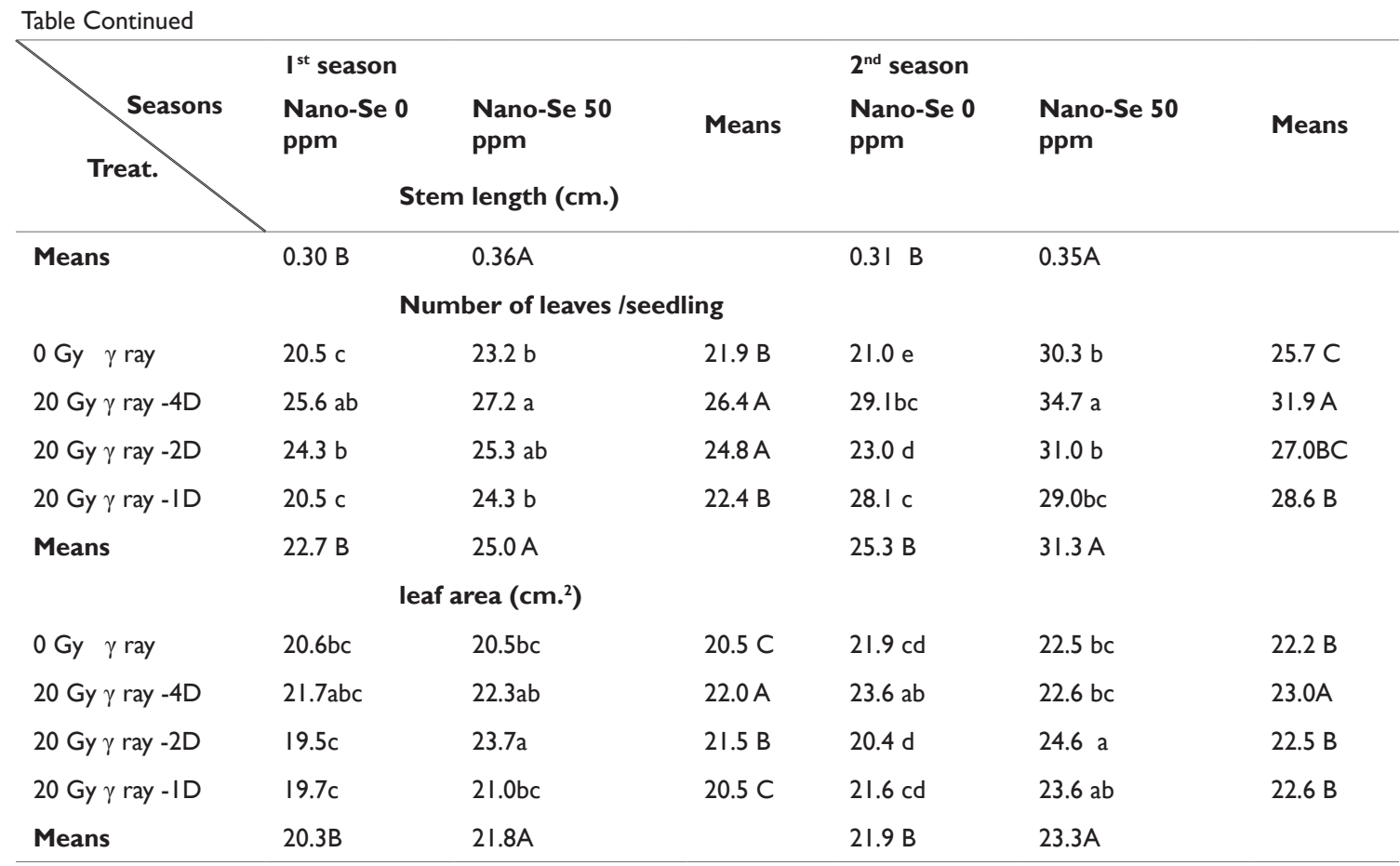

* Mean followed by the same letter are not significantly different at $5 \%$ level.

It's clear that $\gamma$ ray alone or plus pre-sowing seeds in Nano-selenium solution positively improved acid lime seedlings growth. These obtained results are in agreement with Ibrahim and Al-Wasfy ${ }^{45}$ as they reported that, using sodium selenit at $50 \mathrm{ppm}$ improve number of leaves per tree and the leaf area on Valencia orange trees those obtained by Kerkadze ${ }^{46}$ and Khokhar ${ }^{47}$ who observed a decrease in mean seedling height with increasing gamma radiation doses in citrus. Concerning the effect of selenium treatment it has been reported that selenium stimulate shoot growth (length and diameter) even at low concentrations $(1,2,4$, and $6 \mathrm{ppm})$ and the highest values of plant height was recorded at concentration of $10 \mathrm{ppm}$, Aggarwal et al. ${ }^{36}$ on Bean (Phaseolus vulgaris L.), Hawrylak-Nowak ${ }^{48}$ on cucumber seedlings , Kaur $^{49}$ on rough lemon Seedlings and Boghdad et al. ${ }^{50}$ on Faba Bean (Vicia faba L.). Moreover El- Kareem et al. ${ }^{51}$, found that, application of selenium at 0.01 to $0.02 \%$ was very effective in enhancing the leaf area on fruiting of Zaghloul Date Palm (Phoenix dectylifera L.). Likewise Hawrylak-Nowak ${ }^{52}$ mentioned that, foliar application of selenium at $5 \mu \mathrm{mol} \cdot \mathrm{dm}-3$ concentration stimulated maize seedlings growth.

\section{Bio-chemical contents:}

\section{1) Leaf pigments contents:}

Data presented in Table (3) generally, revealed that 20 Gy $\gamma$ ray when fractionated to four doses and applied at four times ( $5 \gamma$ ray / once) treatment of acid lime seeds significantly increased leaf pigments contents: Chl.a (0.82 \& 0.83); Chl.b (0.36 \& 0.37); total Chls. (1.87 $\& 1.89)$ and total carotenoids $(0.63 \& 0.63) \mathrm{mg} / \mathrm{g} \mathrm{F}$.Wt. respectively, when compared to the other treatments for both seasons.

Concerning soaking in Nano-selenium results in Table (3) illustrated that Nano-Se solution had no significant effect on leaf pigments contents during the two studied seasons.

As for the interaction between $\gamma$ ray and pre-sowing soaking in selenium solution, data presented in Table (3) showed a significant effect in both seasons. Whereas, $20 \gamma$ ray when divided to four doses and applied at four times ( $5 \gamma$ ray / once) plus soaking in selenium solution gave the highest chl.a $(0.82 \& 084)$; chl.b $(0.37 \& 0.38)$; total chls. $(1.90 \& 1.91)$ and total caroteoids $(0.64 \& 0.64) \mathrm{mg} / \mathrm{g} \mathrm{F} . W \mathrm{t}$. values respectively. While, $0 \gamma$ ray and pre-sowing in Nano selenium solution gave the lowest values.

Generally, it can be concluded that pre-sowing $20 \gamma$ ray when divided to four doses and applied at four times ( $5 \gamma$ ray / once ) alone or plus soaking in Nano-selenium solution, resulted in a remarkable increasing in leaf pigments content, i.e. chl.a , b and carotenoids under this study in both seasons. These results agreement with those obtained by El-Essawy, ${ }^{53}$ Orabi ${ }^{54,55}$ and Lavola et al. ${ }^{56}$, they mentioned that pre-sowing radiation $\gamma$ ray at low doses and availability of nutrients obviously increased leaf chl.a and b contents.

\section{2) Total indoles and phenols:}

Referring to obtained data in Table (4) it can be noticed that both presowing $20 \gamma$ ray when divided to four doses and applied at four times ( $5 \gamma$ ray / once ) or divided to two doses and applied at two times $(10 \gamma$ ray / once ) significantly increased acid lime leaves total indols (2.28 $\& 2.33)$ and $(2.33 \& 2.38)(\mathrm{mg} / \mathrm{g} \mathrm{D} . \mathrm{Wt}$.), respectively and reduced total phenols contents $(0.67 \& 0.84)$ and $(0.85 \& 0.85)(\mathrm{mg} / \mathrm{g} \mathrm{D} . \mathrm{Wt}$.) respectively, in compared to the other experimental.

Moreover, recorded data in Table (4) illustrated that, pre-sowing seeds in Nano-selenium solution, follow the same trend as gamma radiation treatment, significantly increasing leaf total indoles $(2.09 \& 2.14)$ ( $\mathrm{mg} / \mathrm{g}$ D.Wt. $)$ and reduced the total phenols $(0.81 \& 0.79)(\mathrm{mg} / \mathrm{g} \mathrm{d} . \mathrm{wt}$.) when compared to the control for both seasons.

As for the interaction between the pre-sowing $\gamma$ ray plus soaking in Nano-selenium solution treatments, data presented in Table (4) clarified that, combination of radiating treatment at $20 \mathrm{~Gy}$ as fractionated doses and soaking in $50 \mathrm{ppm}$ Nano-selinum pre-sowing gave the highest total indols (2.94 \& 2.98) (mg/g D.Wt.) and the 
lowest total phenols $(0.64 \& 0.71)(\mathrm{mg} / \mathrm{g}$ D.Wt.) values, respectively. In contrary, pre-sowing $0 \gamma$ ray and soaking in tap water treatment gave the lowest total, indoles (1.27 \& 1.31) (mg/g D.Wt.) and the highest tot phenols $(1.18 \& 1.21)(\mathrm{mg} / \mathrm{g}$ D.Wt.), respectively values in both studied seasons.

Table 3 Effect of pre-sowing $\gamma$ radiation and Nano-Se application on leaf pigments content ( $\mathrm{mg} / \mathrm{g} \mathrm{F.Wt}$.) of acid lime seedlings.

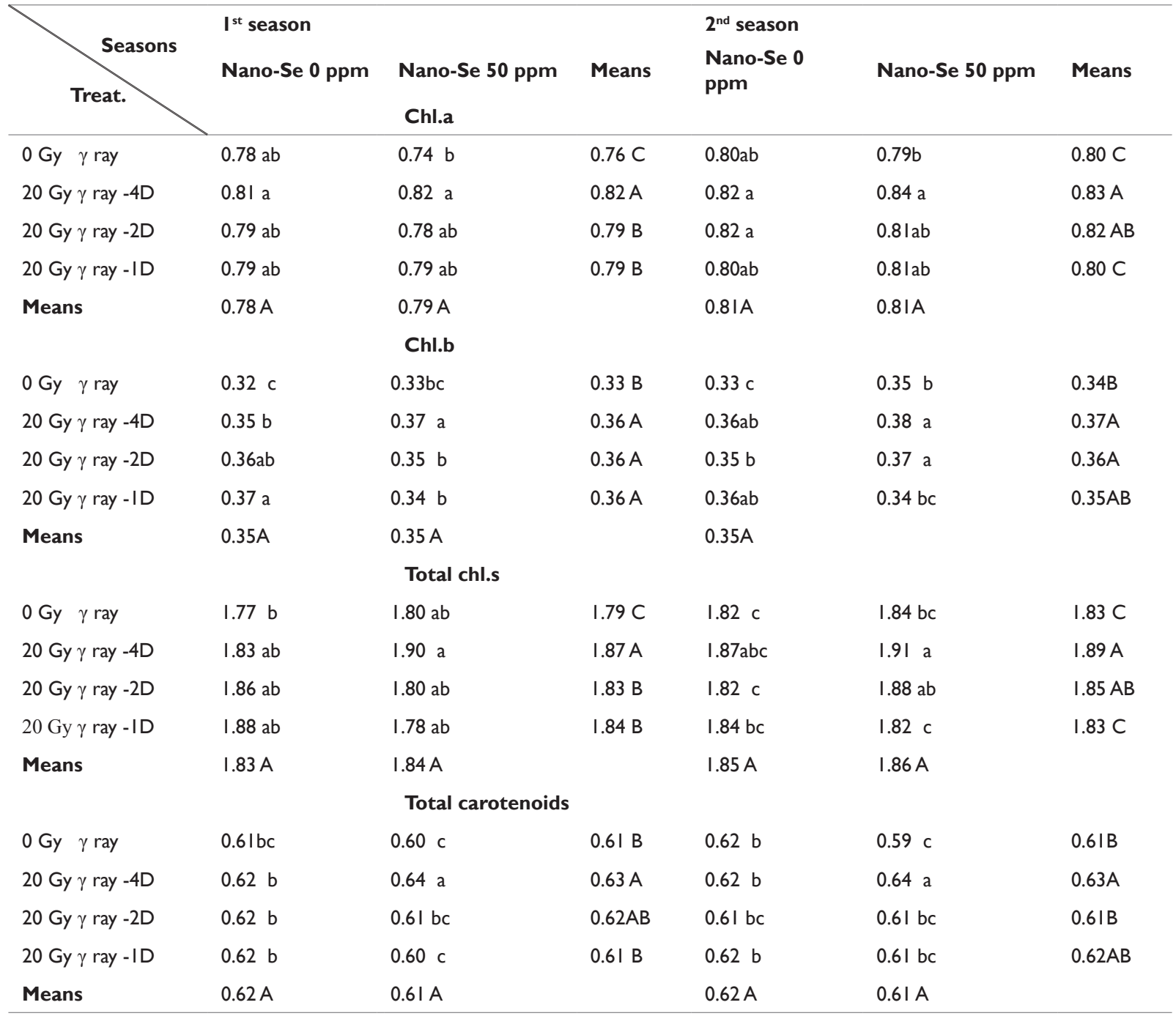

*Mean followed by the same letter are not significantly different at $5 \%$ level.

It can be conclude that pre - sowing acid lime seeds with both of $\gamma$ ray treatments or soaking in Nano - selenium solutions improved seedlings leaves total indoles contents and reduced total phenols. These results are in agreement with those obtained by Sharma et al. ${ }^{5}$, Alfthan ${ }^{9}$, 2014; Banuelos et al. ${ }^{10}$, and El-Ramady et al. ${ }^{11}$, who mentioned that , low-doses of ionizing irradiation on plants seeds of rough lemon (Citrus jambhiri Lush) extracted accelerated cell proliferation, cell growth, enzyme activity, stress resistance and crop yields. Moreover, (Se) applications on fruit orchards have been carried out since tests have confirmed (Se)'s role as a medical substance and must be added for its positive action on seedling growth $\mathrm{s}$. It is considered as a finite and non-renewable resource on the Earth. While there is no evidence of (Se) need for higher plants. Several reports indicated that when (Se) added at low concentrations, (Se) exerts beneficial effects on plant growth and it may act as quasi-essential micronutrient through altering different physiological and biochemical traits. Thus, plants vary considerably in their physiological and biochemical response to selenium.

\section{3) Leaf (macro \& micro) elements content:}

Concerning the effect of pre-sowing $\gamma$ radiation treatment on acid lime seeds leaf macro \& micro elements contents, obtained results in Table (5) clarify that, applying $\gamma$ ray at 20 Gy divided into 4 doses significantly increased both leaf macro- elements N (2.38 \& 2.41)\% ; $\mathrm{P}(0.18 \& 0.19) \%$ and $\mathrm{K}(1.23 \& 1.25) \%$ and micro - elements : $\mathrm{Fe}(95.5 \& 96.10) \mathrm{ppm} ; \mathrm{Zn} \quad(81.8 \& 83.10) \mathrm{ppm}$ and $\mathrm{Mn}(57.10 \&$ 57.4) ppm, respectively for both seasons.

Moreover, data presented in Table (5) illustrated that pre-sowing seeds soaking in Nano-Selenium treatment significantly increased leaf $\mathrm{N}(1.88 \& 1.93) \% ; \mathrm{P}(0.14 \& 0.15) \%$ and $\mathrm{K}$ ( $1.04 \& 1.04) \%$ and Fe (86.80 \& 89.80) ppm ; Zn (66.80 \& 68.90) ppm and Mn (50.40 \& $55.10)$ ppm, respectively during the two studied seasons.

Regarding to the interaction effect between $\gamma$ ray applications and presowing seeds soaking in Nano-selenium solution results in Table (5) indicated that, radiating lime seed with gamma radiation at $20 \mathrm{~Gy}$ 
divided into 4 dose followed by soaking the seeds in $50 \mathrm{ppm}$ Nanoselenium gave the highest $\mathrm{N}(2.51 \& 2.54) \% ; \mathrm{P}(0.18 \& 0.19) \%$ and $\mathrm{K}(1.28 \& 1.29) \% ; \mathrm{Fe}(101.60 \& 104.60) \mathrm{ppm} ; \mathrm{Zn}(88.00 \& 87.70)$ ppm and $\mathrm{Mn}(61.30 \& 60.60) \mathrm{ppm}$ values respectively. And $0 \gamma$ ray plus soaking in tap water treatment was the lowest $\mathrm{N}(1.27 \& 1.33)$ $\% ; \mathrm{P}(0.08 \& 0.10) \%$ and $\mathrm{K}(0.64 \& 0.68) \%$; Fe ( $65.70 \& 66.30)$ ppm ; Zn (44.50 \& 43.10) ppm and Mn (28.50 \& 29.60) ppm values respectively.

Table 4 Effect of pre-sowing $\gamma$ radiation and Nano-Se application on leaf total indole and phenol content (mg/g D.Wt.) of acid lime seedlings.

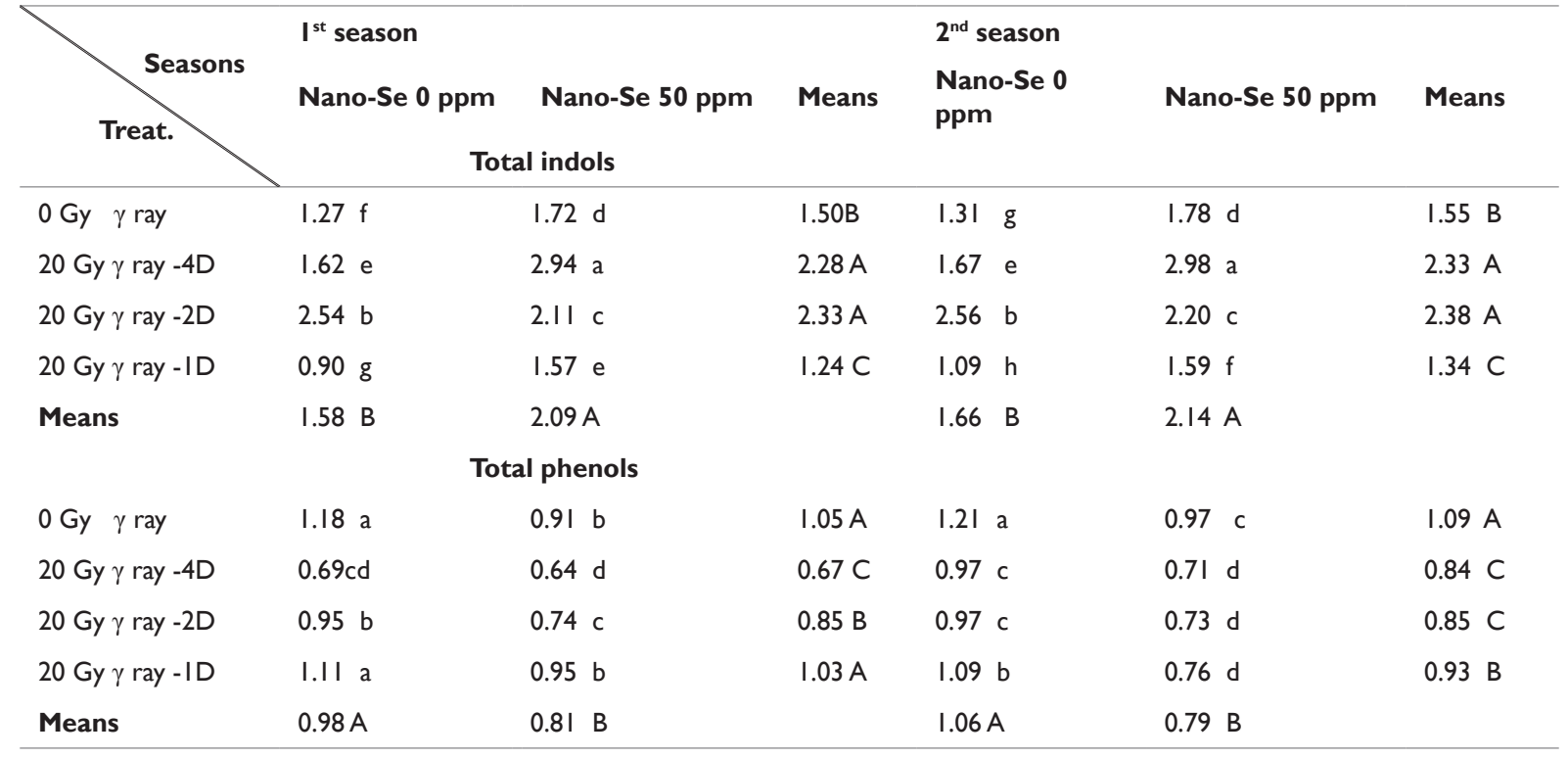

*Mean followed by the same letter are not significantly different at $5 \%$ level.

Table 5 Effect of pre-sowing $\gamma$ radiation and Nano-Se application on leaf (macro \& micro) elements content of acid lime seedlings.

\begin{tabular}{|c|c|c|c|c|c|c|}
\hline \multirow{3}{*}{ Seasons } & \multicolumn{3}{|l|}{ | st season } & \multicolumn{3}{|l|}{$2^{\text {nd }}$ season } \\
\hline & Nano-Se 0 ppm & Nano-Se 50 ppm & Means & $\begin{array}{l}\text { Nano-Se } 0 \\
\text { ppm }\end{array}$ & Nano-Se 50 ppm & Means \\
\hline & \multicolumn{6}{|c|}{ Nitrogen percentage } \\
\hline 0 Gy $\gamma$ ray & $\mathrm{I} .27 \mathrm{f}$ & $1.89 \mathrm{c}$ & $\mathrm{I} .58 \mathrm{BC}$ & $1.33 \mathrm{f}$ & $2.00 \mathrm{c}$ & $\mathrm{I} .66 \mathrm{~B}$ \\
\hline 20 Gy $\gamma$ ray $-4 D$ & $2.24 \mathrm{~b}$ & $2.51 \mathrm{a}$ & $2.38 \mathrm{~A}$ & $2.29 \mathrm{~b}$ & $2.54 \mathrm{a}$ & $2.41 \mathrm{~A}$ \\
\hline 20 Gy $\gamma$ ray $-2 D$ & $1.66 \mathrm{~d}$ & $1.63 \mathrm{~d}$ & $1.65 \mathrm{~B}$ & $1.70 \mathrm{~d}$ & $1.68 \mathrm{~d}$ & $1.69 \mathrm{~B}$ \\
\hline 20 Gy $\gamma$ ray -ID & $1.58 \mathrm{~d}$ & $1.46 \mathrm{e}$ & $1.52 \mathrm{C}$ & $1.63 \mathrm{~d}$ & $1.51 \mathrm{e}$ & $1.57 \mathrm{C}$ \\
\hline \multirow[t]{2}{*}{ Means } & $1.69 \mathrm{~B}$ & $1.88 \mathrm{~A}$ & & I.74 B & $1.93 \mathrm{~A}$ & \\
\hline & \multicolumn{6}{|c|}{ Phosphorus percentage } \\
\hline 0 Gy $\gamma$ ray & $0.08 b$ & $0.13 a b$ & $0.11 B$ & $0.10 \mathrm{~b}$ & $0.14 \mathrm{ab}$ & $0.12 \mathrm{~B}$ \\
\hline 20 Gy $\gamma$ ray $-4 D$ & $0.17 \mathrm{a}$ & $0.18 \mathrm{a}$ & $0.18 \mathrm{~A}$ & $0.18 \mathrm{a}$ & $0.19 \mathrm{a}$ & $0.19 \mathrm{~A}$ \\
\hline 20 Gy $\gamma$ ray $-2 D$ & $0.13 \mathrm{ab}$ & $0.14 a b$ & $0.14 \mathrm{AB}$ & $0.14 a b$ & $0.15 \mathrm{ab}$ & $0.15 \mathrm{AB}$ \\
\hline 20 Gy $\gamma$ ray -ID & $0.10 \mathrm{~b}$ & $0.09 \mathrm{~b}$ & $0.10 \mathrm{~B}$ & $0.11 \mathrm{~b}$ & $0.10 \mathrm{~b}$ & $0.11 \mathrm{~B}$ \\
\hline \multirow[t]{2}{*}{ Means } & $0.12 \mathrm{~B}$ & $0.14 \mathrm{~A}$ & & $0.13 \mathrm{~B}$ & $0.15 \mathrm{~A}$ & \\
\hline & \multicolumn{6}{|c|}{ Potassium percentage } \\
\hline 0 Gy $\gamma$ ray & $0.64 \mathrm{f}$ & $1.14 \mathrm{~b}$ & $0.89 \mathrm{~B}$ & $0.68 \mathrm{~g}$ & $1.10 \mathrm{c}$ & $0.89 \mathrm{~B}$ \\
\hline 20 Gy $\gamma$ ray $-4 D$ & $1.18 \mathrm{~b}$ & $1.28 \mathrm{a}$ & $1.23 \mathrm{~A}$ & $1.21 \mathrm{~b}$ & $1.29 \mathrm{a}$ & $1.25 \mathrm{~A}$ \\
\hline 20 Gy $\gamma$ ray $-2 D$ & $0.82 \mathrm{~d}$ & $0.97 c$ & $0.89 \mathrm{~B}$ & 0.88 e & $0.99 \mathrm{~d}$ & $0.94 \mathrm{~B}$ \\
\hline 20 Gy $\gamma$ ray - ID & $0.69 \mathrm{f}$ & $0.76 \mathrm{e}$ & $0.73 \mathrm{C}$ & $0.70 \mathrm{~g}$ & $0.77 \mathrm{f}$ & $0.74 \mathrm{C}$ \\
\hline \multirow[t]{2}{*}{ Means } & $0.83 \mathrm{~B}$ & $\mathrm{I} .04 \mathrm{~A}$ & & $0.87 \mathrm{~B}$ & $\mathrm{I} .04 \mathrm{~A}$ & \\
\hline & \multicolumn{6}{|l|}{ Iron (ppm) } \\
\hline 0 Gy $\gamma$ ray & $65.7 \mathrm{~h}$ & $69.2 \mathrm{~g}$ & $67.5 \mathrm{D}$ & $66.3 \mathrm{~g}$ & $71.6 \mathrm{f}$ & $69.0 \mathrm{C}$ \\
\hline
\end{tabular}




\begin{tabular}{|c|c|c|c|c|c|c|}
\hline & I st $^{\text {st }}$ season & & & $2^{\text {nd }}$ season & & \\
\hline Se & Nano-Se 0 ppm & Nano-Se 50 ppm & Means & $\begin{array}{l}\text { Nano-Se } 0 \\
\text { ppm }\end{array}$ & Nano-Se 50 ppm & Means \\
\hline & \multicolumn{6}{|c|}{ Nitrogen percentage } \\
\hline 20 Gy $\gamma$ ray -4D & $89.4 \mathrm{~b}$ & $101.6 \mathrm{a}$ & $95.5 \mathrm{~A}$ & $87.6 c$ & $104.6 \mathrm{a}$ & $96.1 \mathrm{~A}$ \\
\hline 20 Gy $\gamma$ ray $-2 D$ & $73.8 \mathrm{e}$ & $87.0 \mathrm{c}$ & $80.4 \mathrm{~B}$ & $77.4 \mathrm{~d}$ & $90.6 \mathrm{~b}$ & $84.0 \mathrm{~B}$ \\
\hline 20 Gy $\gamma$ ray -ID & $71.1 \mathrm{f}$ & $83.0 \mathrm{~d}$ & $77.1 \mathrm{C}$ & $73.6 \mathrm{e}$ & $92.3 \mathrm{~b}$ & $83.0 \mathrm{~B}$ \\
\hline \multirow[t]{2}{*}{ Means } & $73.4 \mathrm{~B}$ & $86.8 \mathrm{~A}$ & & $76.2 B$ & $89.8 \mathrm{~A}$ & \\
\hline & \multicolumn{6}{|l|}{ Zinc (ppm) } \\
\hline 0 Gy $\gamma$ ray & $44.5 \mathrm{~g}$ & $49.5 e$ & $47.0 \mathrm{D}$ & 43.Ih & $50.6 \mathrm{~g}$ & 46.8 D \\
\hline 20 Gy $\gamma$ ray -4D & $75.5 \mathrm{~b}$ & $88.0 \mathrm{a}$ & $81.8 \mathrm{~A}$ & $78.4 b$ & $87.7 \mathrm{a}$ & $83.1 \mathrm{~A}$ \\
\hline 20 Gy $\gamma$ ray $-2 D$ & $66.0 \mathrm{c}$ & $67.1 \mathrm{c}$ & $66.5 \mathrm{~B}$ & $69.4 d$ & $74.5 \mathrm{c}$ & $72.0 \mathrm{~B}$ \\
\hline 20 Gy $\gamma$ ray -ID & $47.2 \mathrm{f}$ & $62.6 d$ & $54.9 \mathrm{C}$ & $54.2 f$ & $62.7 \mathrm{e}$ & $58.45 \mathrm{C}$ \\
\hline \multirow[t]{2}{*}{ Means } & $58.3 B$ & $66.8 \mathrm{~A}$ & & $61.3 \mathrm{~B}$ & $68.9 \mathrm{~A}$ & \\
\hline & \multicolumn{6}{|l|}{ Manganese (ppm) } \\
\hline 0 Gy $\gamma$ ray & $28.5 \mathrm{~g}$ & $32.5 \mathrm{f}$ & $30.5 \mathrm{D}$ & $29.6 \mathrm{~g}$ & $35.2 \mathrm{f}$ & $32.4 \mathrm{D}$ \\
\hline 20 Gy $\gamma$ ray $-4 D$ & $52.9 b$ & $61.3 \mathrm{a}$ & 57.IA & $54.0 \mathrm{~b}$ & $60.6 \mathrm{a}$ & $57.4 \mathrm{~A}$ \\
\hline 20 Gy $\gamma$ ray $-2 D$ & $37.5 e$ & $60.1 \mathrm{a}$ & $48.8 \mathrm{~B}$ & $38.2 \mathrm{e}$ & $60.4 \mathrm{a}$ & $49.2 \mathrm{~B}$ \\
\hline 20 Gy $\gamma$ ray -ID & $42.2 d$ & $47.7 \mathrm{c}$ & $44.9 \mathrm{C}$ & $45.7 d$ & $48.4 \mathrm{c}$ & $47.0 \mathrm{C}$ \\
\hline Means & $40.3 B$ & $50.4 \mathrm{~A}$ & & $41.9 B$ & 5I.IA & \\
\hline
\end{tabular}

*Mean followed by the same letter are not significantly different at $5 \%$ level.

Generally, it could be concluded that pre-sowing seeds irradiating with $\gamma$ radiation particularly at 20 Gy divided into 4 dose or soaked in Nano (Se) at (50 ppm) encouraged absorption, translocation and accumulation of N; P and $\mathrm{K}$ and Fe; $\mathrm{Zn}$ and $\mathrm{Mn}$ in leaves. These results are agreement with those obtained by: Satter et al. ${ }^{57}$, on soybean who reported that low $\gamma$ ray doses increased nitrogen content. In the same concern, Korosi and Krakkai ${ }^{58}$ pointed out that exposure of (Phaseolus vulgaris L.). seeds to $10 \mathrm{~Gy} \gamma$ ray stimulate phosphorus uptake but high dose 120Gy inhibit phosphorus uptake, on Datura plants, $\gamma$ ray from 1 to $15 \mathrm{~K}$ rad doses had significant effect on some nutrients. Maximum value of $\mathrm{K}$ in leaves was obtained at $5 \mathrm{k}$ rad. Also, irradiating gladiolus corms with low $\gamma$ ray doses increased $\mathrm{K}$ content El-Essawy. ${ }^{53}$ Finally, Mohamed et al. ${ }^{59}$, and Orabi ${ }^{54,55}$ reported that irradiating seeds of some vegetable crops before sowing with low doses up to $20 \gamma$ ray increased $\mathrm{P}$ concentration in leaves, while dose of $40 \gamma$ ray decreased it.

\section{Protein analysis}

Data represents in Figure (1) reveal that the banding pattern of protein peptides in treated and untreated acid lime (Citrus aurantifolia L.) with $\gamma$ ray. In total, 21 protein subunits were observed. Variability in intensity was observed in some bands that indicated the quantity of protein peptides cumulating at a particular molecular weight. The protein markers plotted for first principal components that revealed 7 distinct groups Figure (1). Principal component analysis based on SDS-PAGE revealed clear grouping pattern when investigated for treatment with $\gamma$ ray. The genotypes of acid lime seedlings (Citrus aurantifolia L.) untreated $0.0 \gamma$ ray; treated with $\gamma$ ray at $20 \mathrm{~Gy}$ fractionated as 4 doses; treated with $\gamma$ ray at 20 Gy fractionated as 2 doses and treated with $\gamma$ ray at 20 Gy as single dose were separated clearly with no clear variable differences between treated acid lime seedlings with $\gamma$ ray and the control. Acid lime (Citrus aurantifolia L.) seedlings treated with different doses of $\gamma$ ray showed clear separation of protein pattern like the control with distinctive 7 main protein bands. The obtained results showed no differences in the protein pattern between treated and untreated lime seedlings with $\gamma$ ray, which means lime seedlings, could be treated with certain doses and conditions according to the type of plants without affecting the genotype.

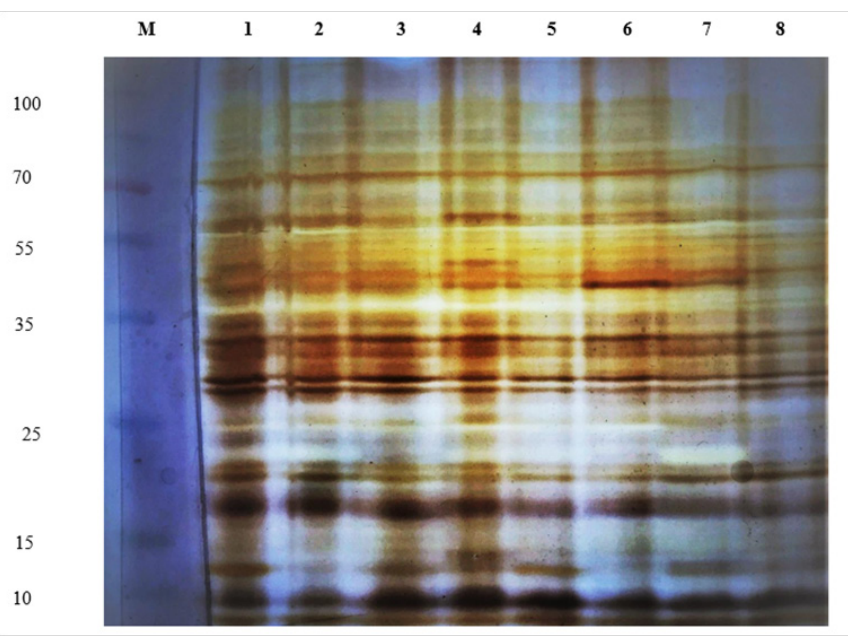

Figure I SDS-PAGE separation of high molecular weight (HMW) and low molecular weight (LMW) protein subunits from acid lime (Citrus aurantifolia L.) seedlings treated and untreated with $\gamma$ ray. M, represents molecular weight marker (Prestained Dual Color Protein) Molecular Weight Marker (10-250 $\mathrm{kDa}$ ); I and 5 , acid lime seedlings were untreated 0.0 Gy $\gamma$ ray; 2 and 6 , acid lime seedlings were treated with $\gamma$ ray at $20 \mathrm{~Gy}$ fractionated as 4 doses; 3 and 7 , acid lime seedlings were treated with $\gamma$ ray at 20 Gy fractionated as 2 doses; 4 and 8 , acid lime seedlings were treated with $\gamma$ ray at $20 \mathrm{~Gy}$ as single dose. 


\section{Conclusion}

As a conclusion, pre-sowing $\gamma$ ray irradiation of seeds with low doses in particular at $20 \mathrm{~Gy}$, fractionated as 4 doses ( $5 \gamma$ ray / once ) plus soaked in Nano-selenium solution at $50 \mathrm{ppm}$, greatly improved acid lime seeds germination percentage; damping off percentage; albino percentage; seedlings vegetative growth; leaf bio- chemical contents and leaf (macro \& micro) elements.

\section{Recommendation}

It can be recommended that pre- sowing acid lime (Citrus aurantifolia L.) seeds exposure to $20 \mathrm{~Gy} \gamma$ ray when divided to four doses and applied at four times ( $5 \gamma$ ray / once ) treatment plus soaking in Nanoselenium solution (50 ppm).

\section{References}

1. Khan MM, Al-Yahyai R, Al-Said F. The Lime: Botany, Production and Uses. CABI; 2017.

2. Khatana KJ. Influence of GA3 on Germination and growth of acidlime $\mathrm{Cv}$. Kagzilime seed (Citrus aurantifolia Swingle) Under field as well as net house conditions. 2012.

3. Ashraf M, Foolad MR. Pre-sowing seed treatment-A shotgun approach to improve germination, plant growth, and crop yield under saline and non-saline conditions. Adv Agron. 2005;88:223-271.

4. Afzal I, Aslam N, Mahmood F, Hameed A, Irfan S, Ahmad G. Enhancement of germination and emergence of canola seeds by different priming techniques. 2004.

5. Sharma LK, Kaushal M, Gill MIS, Bali SK. Germination and survival of Citrus jambhiri seeds and epicotyls after treating with different mutagents under in vitro conditions. Middle-East J Scintific Res. 2013;16(2):250255 .

6. Maity JP, Mishra D, Chakraborty A, Saha A, Santra SC, Chanda S Modulation of some quantitative and qualitative characteristics in rice (Oryza sativa L.) and mung (Phaseolus mungo L.) by ionizing radiation. Radiat Phys Chem. 2005;74(5):391-394.

7. Zaka R, Chenal C, Misset MT. Effects of low doses of short-term gamma irradiation on growth and development through two generations of Pisum sativum. Sci Total Environ. 2004;320(2-3):121-129.

8. Patade VY, Suprasanna P, Bapat VA. Gamma irradiation of embryogenic callus cultures and in vitro selection for salt tolerance in sugarcane (Saccharum officinarum L.). Agric Sci China. 2008;7(9):1147-1152.

9. Alfthan G, Eurola M, Ekholm P, et al. Effects of nationwide addition of selenium to fertilizers on foods, and animal and human health in Finland: From deficiency to optimal selenium status of the population. $J$ Trace Elem Med Biol. 2015;31:142-147.

10. Bañuelos GS, Arroyo I, Pickering IJ, Yang SI, Freeman JL. Selenium biofortification of broccoli and carrots grown in soil amended with Se-enriched hyperaccumulator Stanleya pinnata. Food Chem. 2015;166:603-608.

11. El-Ramady H, Abdalla N, Taha HS, et al. Selenium and nano-selenium in plant nutrition. Environ Chem Lett. 2016;14(1):123-147.

12. Cheng G, Cheng J. Nanosize selenium-rich compound fertilizer for promoting longevity of house flowering plants. CN Pat. 2010;101851136(6).

13. Buchs B, Evangelou MW, Winkel LH, Lenz M. Colloidal properties of nanoparticular biogenic selenium govern environmental fate and bioremediation effectiveness. Environ Sci Technol. 2013;47(5):24012407.
14. Singh G, Rattanpal H. Use of nanotechnology in horticulture: a review. Int J Agric Sc Vet Med. 2014;2:34-42.

15. Hartmann HT, Kester DE. Plant Propagation: Principles and Practices. Prentice-Hall.; 1975.

16. Moran R. Formulae for determination of chlorophyllous pigments extracted with $\mathrm{N}, \mathrm{N}$-dimethylformamide. Plant Physiol. 1982;69(6):1376-1381.

17. Larsen P, Harbo A, Klungsöyr S, Aasheim T. On the biogenesis of some indole compounds in Acetobacter xylinum. Physiol Plant. 1962;15(3):552-565.

18. Selim HH, Fayek MA, Sweidan AM. Reproduction of Bircher apple cultivar by layering [Egypt]. Ann Agric Sci Moshtohor. 1978.

19. Horwitz W, Albert R. The Horwitz ratio (HorRat): a useful index of method performance with respect to precision. $J A O A C$ Int. 2006;89(4):1095-1109.

20. Cottenie A. Soil and Plant Testing as a Basis of Fertilizer Recommendations.; 1980.

21. Plummer D. An introduction to practical bio-chem. Mc Graw Hill Co. $1978 ; 2$ nd ed.

22. Murphy J, Riley JP. A modified single solution method for the determination of phosphate in natural waters. Anal Chim Acta. $1962 ; 27: 31-36$.

23. Piper CS. Soil and Plant Analysis. University of Adelaide. Interscience Published. Inc N Y. 1950:258-275.

24. Bradfield EG, Spincer D. Leaf analysis as a guide to the nutrition of fruit crops. VI-Determination of magnesium, zinc and copper by atomic absorption spectroscopy. J Sci Food Agric. 1965;16(1):33-38.

25. Laemmli UK. Cleavage of structural proteins during the assembly of the head of bacteriophage T4. nature. 1970;227(5259):680-685.

26. Rabilloud T, Carpentier G, Tarroux P. Improvement and simplification of low-background silver staining of proteins by using sodium dithionite. Electrophoresis. 1988;9(6):288-291.

27. Allam E, Badawi M, El-Khatib A, Haggag S, Mahmoud M. Characterization and Applications of Nano Lead Oxide as A Shielding Material for Gamma Radiation. In: Alexandria, Egypt; 2012.

28. Snedecor GW. Cochran. WG, Statistical Methods. Ames, Iowa State University Press; 1967.

29. Duncan DB. Multiple range and multiple F tests. Biometrics. 1955;11(1):1-42.

30. Mondal B, Pal A, Saha R. Detection of zygotic embryos of Citrus reticulata by Random Amplified Polymorphic DNA technique. Int $J$ Sci Res. 2014;3:768-773.

31. Batygina TB, Vinogradova GY. Phenomenon of polyembryony. Genetic heterogeneity of seeds. Russ J Dev Biol. 2007;38(3):126-151.

32. Ling APK, Chia JY, Hussein S, Harun AR. Physiological responses of Citrus sinensis to gamma irradiation. World Appl Sci J. 2008;5(1):12-19

33. Kumar A, Mishra MN. Effect of gamma-rays EMS and NMU on Germination, Seedling Vigour, Pollen viability and plant survival in M, and M generation of okra (Abelmoschusesculentus L. Moench). Adv Plant Sci. 2004; 17 (1): 295-297.

34. Shahverdi MA, Tabatabaei SJ. Effect of nutri-priming on germination indices and physiological characteristics of stevia seedling under salinity stress. J Seed Sci. 2017; 39 (4): 353-362.

35. Luís R, Ermelinda S, Helena F. Effects on germination and early growth of Triticum aestivum L. cv. "Jordão" under different concentrations of (Se). In: Jordão; 2016. 
36. Aggarwal M, Sharma S, Kaur N, et al. Exogenous proline application reduces phytotoxic effects of selenium by minimising oxidative stress and improves growth in bean (Phaseolus vulgaris L.) seedlings. Biol Trace Elem Res. 2011;140(3):354-367.

37. Carlson CL, Kaplan DI, Adriano DC. Effects of selenium on germination and radicle elongation of selected agronomic species. Environ Exp Bot. 1989;29(4):493-498.

38. Abdel-Hady MS, Okasha EM, Soliman SSA, Talaat M. Effect of gamma radiation and gibberellic acid on germination and alkaloid production in Atropa belladonna L. Aust J Basic Appl Sci. 2008;2(3):401-405.

39. Jan S, Parween T, Siddiqi TO. Effect of gamma radiation on morphological, biochemical, and physiological aspects of plants and plant products. Environ Rev. 2012;20(1):17-39.

40. Spiegel-Roy P, Kochba J. Mutation breeding in citrus. In: Induced Mutations in Vegetatively Propagated Plants. ; 1973.

41. Spiegel-Roy P, Teich AH, Kochba J. Gamma irradiation and pollen cultivar influence on polyembryony of "satsuma"(Citrus Unshiu marc.). Radiat Bot. 1972;12(5):365-367.

42. Lange H, Toit W. Gamma irradiation of citrus material. In: Bulletin, Citrus and Subtropical Research Institute. Vol 8. Nelspruit, South Africa: Citrus and Subtropical Research Institute; 1977.

43. Vose PB. Introduction to Nuclear Techniques in Agronomy and Plant Biology: Pergamon International Library of Science, Technology, Engineering and Social Studies. Elsevier; 2013.

44. Jawaharlal M, Thangaraj T, Irulappan I. Influence of rootstock on the post-harvest qualities of acid lime fruit. South Indian Hort. 1991;39:151152 .

45. Ibrahim HIM, Al-Wasfy MM. The promotive impact of using silicon and selenium with potassium and boron on fruiting of Valencia orange trees grown under Minia region conditions. World Rural Obs. 2014;6(2):2836.

46. Kerkadzi IG. Induced mutations in subtropical crops. V. Biological and genetic effect of treating citrus with gamma-radiation. Subtrop Kul. 1985;4:104-110.

47. Khokhar R. Studies on mutagen induced variability in Kinnow mandarin. 1998.

48. Hawrylak-Nowak B. Beneficial effects of exogenous selenium in cucumber seedlings subjected to salt stress. Biol Trace Elem Res. 2009; 132(1-3):259-269.
49. Kaur S. Effect of mutagens on regeneration and growth of in vitro grown epicotyl segments of rough lemon seedlings (Citrus jambhiri Lush.). $J$ Appl Nat Sci. 2015;7(1):459-465.

50. Boghdad M, Desoky E, Azoz S, Dalia MN. Effect of Selenium on Growth, Physiological Aspects and Productivity of Faba Bean (Vicia faba L.). EgyptJAgron. 2017;1(39):83-97.

51. El-Kareem MG, Aal AA, Mohamed AY. The Synergistic Effects of Using Silicon and Selenium on Fruiting of Zaghloul Date Palm (Phoenix dectylifera L.). World Acad Sci Eng Technol Int J Biol Biomol Agric Food Biotechnol Eng. 2014;8(3):259-262.

52. Hawrylak-Nowak B. Effect of selenium on selected macronutrients in maize plants. J Elem. 2008;13(4):513-519.

53. El-Essawy M. Effect of radiation and gibberllic acid on the growth and flowering of Gladiolus corms. 1995.

54. Orabi I. Effect of treating seeds GA3 and / or gamma irradiation on growth, chemical composition, flowering and seed production and its quality of eggplant (Solanum melongena L. ). In: Effect of Treating Seeds GA3 and / or Gamma Irradiation on Growth, Chemical Composition, Flowering and Seed Production and Its Quality of Eggplant (Solanum Melongena L. ). Vol 12. 12. Egypt: J. Appl. Sci; 1997:920-933.

55. Orabi IOA. Effect of seed irradiation and salinity on growth, chemical composition, flowering and seed production and its quality of cowpea. Egypt J Appl Sci. 1998;13(1):201-215.

56. Lavola A, Aphalo PJ, Lahti M, Julkunen-Tiitto R. Nutrient availability and the effect of increasing UV-B radiation on secondary plant compounds in Scots pine. Environ Exp Bot. 2003;49(1):49-60.

57. Sattar A, Neelofar, Akhtar MA. Irradiation and germination effects on phytate, protein and amino acids of soybean. Plant Foods Hum Nutr. 1990;40(3):185-194. doi:10.1007/BF01104141

58. Korosi F, Krakkai I. Effect of gamma radiation of Pharsalus . vulgaris L. seeds on 32po4-3 uptake of seedlings and its translocation pattern. In: Vol 23. 2nd ed. Hort. Abst.; 1983:149-153.

59. Mohamed FA, Hefni SM, Maghraby GM. Effect of pre-planting gamma radiation on peanut plant. In: Proc. 2nd Conf. Agric. Dev. Res.(Ain Shams Univ.) IV. ; 1988:130-142.
Citation: Ahmed HS,Ahmed MF, Shoala T, et al. Impact of Single or Fractionated Radiation and Selenium Nano-particles on Acid Lime (Citrus aurantifolia L.) Seed Germination Ability and Seedlings Growth. Adv Agr Environ Sci. (20l8); (2): 9I-I00. DOI: 10.3088I/aaeoa.00016 